\title{
The Rise of Feminism and the Growth of Black American Women Literature
}

\author{
Dr. Prasanta Kumar Padhi \\ Department of English, Orissa Engineering College
}

\begin{abstract}
The tragedy of African-American women comes from racial segregation which is the result of long term slavery. Also it stems from gender discrimination. They had to live with the tortures of gender discrimination perpetrated by not only white men but also men of same race. For Black women, their concern with feminism is usually more group-centered than self-centered, more cultural than political. As a result, they tend to be concerned more with the particular female cultural values of their own ethnic group rather than with those of women in general. These are the most intriguing questions that have provoked the black feminists to think deeply and write on the themes and subjects that directly relate to the black woman culture. This movement chiefly got added strength with the support of writers like Weldon Johnson, Claude Mackay, Sterling Allen Brown, Nella Larsen, Jean Toomer, Zora Neale Hurston and many others who came forward expressing vigorously the life and problems of Black women in their writings. The new Negro or black American literature became forceful and most arresting chiefly because it was based on the real experiences as well as long miseries and sufferings of the black people under the slavery system much before the civil war. Since the entire literature was rooted in the real life and sufferings of the black, it has its direct appeal to the reading public.
\end{abstract}

Key words: Emancipation, struggle, portrayal, exploitation, awareness

The picture of miseries and sufferings of the Black woman in America may appear, perhaps darker and more dismal than Dante's description of Hell. For, in the history of human race, no one has suffered more than the Black woman in a civilized country like America. A close and critical exposition of the history of the Black woman's life and condition since her arrival in a strange land will unfold very well the long story of her agony and sorrow associated with her mutilated soul. Since her arrival on the alien shore, the Black woman has been subjected to the worst kind of exploitation and oppression. As a Black she has had to endure all the horrors of slavery and, living in a racist society as a worker, she has been the object of continual exploitation, occupying the lowest place on the wage scale and restricted to the most demeaning and uncreative jobs. As woman she has seen her physical image defamed and been the subject of White master's uncontrollable lust and subjected to all the ideals of white womanhood as a model to which she should aspire. Since times of slavery, Black womanhood has been destroyed, distorted, dismantled and abused with racial, sexual and inhuman practices by black men and white men and women. In the process, they have lost their genuine "self", and have developed a complexity in themselves. They see themselves with the eyes of white men and women and black men. This has ultimately been responsible for the destruction of their self-confidence and the feeling of being human. They looked upon themselves as chattels.

As a mother she has seen her children torn from her breast and sold into slavery. She has seen them left at home without attention while she attended to the needs of the offspring of the ruling class. She has seen her children afflicted by dope addiction, the lack of decent education and subjected to attacks by a racist society, legal lynching, cannon fodder for America's imperialist wars of aggression and populating the prisons of this nation. In addition, besides suffering the common fate of all oppressed and exploited people, the AfroAmerican women continues to experience the age-old oppression of woman by men. In the home she becomes "the slave of a slave". By giving woman a false feeling of superiority in the home or in relationships with women, certain aspects of capitalist tension are alleviated. The grate matter of pity is that men may be cruelly exploited and subjected to all sorts of dehumanizing tactics on the part of the ruling class, but at least they can take out their frustration on someone else, their women.

Even the end of slavery did not give the Black woman any greater right to sexual integrity. They were still at the mercy of the carnal desires of white men and the Black man could not protect her unless he was prepared to lose his life in her defense. White men were able to use the economic deprivation of black women to their sexual advantage. The total picture of Black women emerged from what Nanny says to her granddaughter:

Honey, de white is the de ruler of everything as fur as Ah been able tuh find out.

Maybe it's some place way of in de ocean where de black man is in power, but we don't know nothing but we see. So de white man throw down de load and tell de nigger man tuh pick it up. He pick it up because he have to, but he don't tote it. He 
had it to his women folks. De nigger woman is de mule uh de world so fur as Ah can see.(Huston, 16)

With these words Nanny, an elderly African-American woman explains the Black women's place to her young granddaughter as she knows that being treated as "mules uh de world" lies at the heart of Black women's oppression.

This being the dark portrait of the Black woman, there appeared a ray of hope with the rise of feminism. But feminism that first started in England has altogether a different meaning and context by such writers like Virginia Woolf and others. Most people in the United States think of feminism or the more commonly used term "Women's Lib" as a movement that aims to make women the social equal of men. In fact feminism as a movement has its root in the social structure and social circumstances. This has been correctly Bell Hooks in her book Feminist Theory: From Margin to Centre:

My awareness of feminist struggle was stimulated by social circumstance. Growing up in a Southern, black, father dominated, working class household, I experienced (as did my mother, my sisters, and my brother) varying degrees of patriarchal tyranny and it made me angry- it made dominance and enabled me to resist sexist socialization. Frequently White feminist act as if black women did not know sexist oppression existed until they voiced feminist sentiment. They believe they are providing black woman with "the" analysis and "the" program for liberation. They do not understand, cannot even imagine, that black women, as well as other groups of women who live daily in oppressive situations, often acquire an awareness often patriarchal politics from their lived experience, just as they develop strategies for resistance(even though they may not resist on a sustained or a organized basis (Hooks, 10)

It is true that the growth in feminist consciousness was a consequence of the educational efforts of the women's movement as well as the continued integration of women into a nontraditional lifestyle. Feminist leaders incorporated their sentiment a coherent ideology, which defined sex discrimination as women's problem, held the government responsible for ending this unfair treatment, and offered a plan of action to ease women's burden. In short, the women's experience changed radically, resulting in the beginning of a new lifestyle centered around work rather than the home.

Thus feminism in America means much more than what it stands in other European countries, chiefly because it has different role and connotation with respect to the Black women. If a feminist is commonly defined as one who is involved in transforming and reinterpreting familiar realities, then Black women are innately feminists. Black women writing exhibits and constructs a Black women's literary tradition that is inherently feminist. Barbara Smith, an influential Black feminist critic, states that the ability of Black women to survive in the face of White America exhibits an innate feminist potential.

Black women writers have been concerned with expressing what constitutes a Black woman's reality. The simplistic notions that there is one reality, is constantly refuted by Black women writers. They rejected the notion that literature is supplemental to prior givens that the universal element is the only criterion for evaluating a work. The literature of the Black women was known as invisible till recently. This reveals the truth about a society that is controlled and repressed by the majority and their literature 'creates' the truth for society's 'other', the Black woman. From Phyllis Wheatly's slave narrative in the eighteen century to Toni Morrison's novel Home(2012), one sees pictures of the Black women who sustained and continue to sustain the emancipation of their people.

Historically, the Black woman has been the central figure in the Abolitionist and Emancipation Movements of the nineteenth and twentieth century. Evans in Personal Politics states that "twice in the history of the United States the struggle for racial equality has been mid-wife to a feminist movement- in the abolition movement of the 1830's and again in the Civil Rights movement of the 1960's (Evans, 24). Angela Davis in Race, Sex, Class traces the history of the Black woman from slavery to the present. She outlines how the Black woman was denied her femaleness in race issues and denied her blackness in sex issues. Both these indices were critical in determining the rights of Black men and White women. The Black women became the scapegoat at the altar of emancipation. Sojourner Truth's famous speech 'Ain't I woman' testifies to the double jeopardy of Black women who had to place the survival of her race before that of her race.

In 1831 this refusal to acknowledge the Black woman's presence caused Mari W. Stewart to cry 'how long shall the fair daughters of Africa be compelled to bury their minds and talents beneath the load of iron pots and kettles?'(Lerner, 563). It seems that while White women accepted Black women as women, they could not accept them because they were also Black. They enjoined their cause to that of the Black men. Thus Black women's writing exhibits a 'generational continuity' which preserves both cultural values and personal history. The careful recording of and the resurrection of the buried lives of Black women writers has resulted in a Black 
feminist literary tradition that shows and confirms the shared sisterhood and how thematically, stylistically, aesthetically and conceptually Black women writers manifest common approaches.

One of the foremost preoccupations of Black woman feminists has been to subvert the denigrating image of Black woman. Black women writers often perceive their characters from this angle and have struggled with the burden of the received image. The healing of the wounds inflicted by slavery and racism is attempted through subverting these images. This blending of symbolic with the imaginary is what makes Black women's writing both alien and real and has helped to achieve their self- hood. Thus inspired by the new Lib. Women movement, and encouraged by the white woman's demand for her equality in love, the Black woman was urged upon to overcome her long suffering and raised her voice boldly and courageously in her own writings. As such many Black women have been in the forefront of the black literary movement. However, the significance of their contribution to the Black literature had only been accepted by critics few years back. The miserable condition of Afro-American women has been depicted by Afro-American women writers such as Zora Neale Hurston, Alice Walker, Toni Morison, Harriet Jacob, and many others. Those literary works mostly depict sufferings faced by Afro-American women in American society.

In fact, it is Philip Whitley, a Black woman who laid down the foundation of Black American literary tradition. She published her Poems on Various Subjects, Religious and Moral in 1773. Whitley gave birth to the genre of essays and Harriet E. Wilson, another black woman, initiated the tradition of novel in the United States. Her novel Our Nig: Or Sketches from the Life of a Free Black is the first novel by a black woman. It is also the first novel in Black American literature to examine the life of an ordinary black person in realistic detail. Wilson patterned her novel after real life, a life Wilson herself had lived as a quasi-free Black. Wilson indicated through Our Nig how the northern caste system and southern slavery were interrelated. The novel has many autobiographical elements in it. In fact Our Nig is the first Black romance published in America that explores the plight of a woman whose life, as an indentured servant duplicates that of her enslaved sisters.

Pauline Hopkins, a black woman, editor of Colored American Magazine published in Boston from 1902 to 1904, and the author of the novel Contending Forces has a different intention. In the preface to Contending Forces she wrote that black must use fiction to preserve race memories:

It is a record of growth and development from generation to generation. No one will

do this for us. We must ourselves develop the men and women who will faithfully

portray the inmost thoughts and feelings of the Negro with all the fire and romance

which lie dormant in our history.(Hopkins, 10)

Jessie Fauset, a literary editor of the Crisis from the 1919 to 1926 has four novels to her credit: Cofusion(1924), Plum Bun(1926), The China Berry Tree(1931) and Comedy: American Style (1934). These novels portray middle class Black Americans who are striving for middle class goals that the Black Americans share values similar to those held by whites, a goal that Fausset explicitly acknowledged. Those novels document a fact of black culture in which the author's predominant aim is to convince whites that blacks are like them. Her aim was to emphasize the similarities between the blacks and the whites, rather than the differences.

Till 1940s, most Black women fiction writers tried their level best to change the negative images imposed upon all Black women, images mainly "masculine" according to the norms of the times. Nonetheless from Iola Leroy (1895) to Dorothy West's The Living is Easy (1948) there is an incredible tension between the "femininity" of the heroines and their actual behavior. On the other hand, the writers try to prove that Black women are women, that they are beautiful, pure, upper class, and would not be aggressive, dependent beings. At the same time they appear to believe that if Afro-American women were to achieve the norm, they would lose important aspects of themselves. The novels, especially those about negative portrayal of Black women embody this tension. But even in novels that do not focus on this theme, the writers emphasize their self-directedness of their women characters as well as their light-skinned beauty and Christian morality.

It is significant to note that a large number of texts on Black feminist writings appeared with the following titles that could reclaim to have started a new tradition in American literature as observed by Ann Du Cille in her article "The Occult of True Black womanhood: Critical Demeanor and Black Feminist":

The Black Woman; The Black Woman: an Anthology: The Black Woman in America; The Black Woman in American Society; The Black Woman CrossCulturally; Black Woman in America; The Black Woman in White America; The Black Woman in Nineteenth Century American Life; Black Woman Writers; Black Woman Writers at Work; Black Woman Writing Autobiography; Black Women Writing the American Experience; Black Women Novelists; Black Women Novelists in the Wake of the Civil Rights Movement; Black Women, Fiction and Literary Tradition; the sexual Mountain and Black Women Writers; Ain't I a Woman?; Aren't I a Woman? (Cille, 591)

Similarly many other anthologies of the writings of black feminists appeared with different designs and purpose of leaving astounding impressions on the minds of the readers regarding the bondage and suffering of 
Black woman. This is evidenced in Black Eyed Susans (1975)- an anthology of Black women's writings. Mary Helen Washington has pointed out that this anthology symbolized the "power of art to demolish stereotypes; and if power... is the ability to name one's own experience, Susans was first step towards power, for it celebrated the legends of Black women, weaved dreams into myths that allowed us to recover and name our past"(Washington, xiii). Thus Black women articulated centuries of their collective oppression through their writings. In walker's The Third Life of Grange Copeland (1970), the fate of Black women caught in the vertex of the sharecropping system- the south's substitute of slavery - was flushed out in its grim historical contours. In The Bluest Eye (1970), Morrison traced the damage caused by color consciousness. Walker's In Love and Trouble (1973), and Gayl Jon's Jubilee amply fulfilled the mandate laid down by Angella Davis:

The myth of Black matriarchy and the castrating Black female must be consciously repudiated as myth and the Black woman in her true historical contours must be redirected. We, the Black woman of today, must accept the full weight of a legacy wrought in blood by our mothers in chains... as heirs to a tradition of supreme perseverance and heroic resistance, we must hasten to take our place wherever our people are forging towards freedom.(Walker,15)

Having paid tribute to her 'mothers in chain', having reclaimed history- where the dominant female image was on despair, humiliation and suppression- Black women writers moved on to a different state. The novels that emerged during the latter half of the seventies exhibited a strong feminist perspective as black women writers involved themselves in the task of forging powerful and positive images of Black womanhood. If the involvement with history helped black writers gain a perspective on the forms of oppression black women have had to face- biological, cultural, social and economic- it was political activism which gave them the impetus to shape their own identities. Alice walker, for example, has outlined a personal, historical view of Black women: she sees Black women moving from a state of total victimization by society and by men to a state of growth and development where they have more control over their lives. In her vision of the final cycle in the evolutionary process, Walker speaks of what she calls 'the emergent women'. Washington points out that 'emergent women' are women who are women who "are greatly influenced by the political events of the sixties and the changes resulting from the freedom movement: they are women coming just to the edge of a new awareness and making the first tentative steps to an uncharted region".(Washington, 22)

By the mid-seventies, Afro-American women fiction writers, like Paule Marshall, Toni Morrison, Alice Walker, Toni Cade Bambara, and Gayle Jones had not only defined their cultural context as a distinctly AfroAmerican one, but they had also probed many facets of the interrelationship of sexism and racism in their society. Not only had they demonstrated the fact that sexism existed in black communities, but they had also challenged the prevailing definition of woman in American society, especially in relation to motherhood and sexuality. And they had insisted not only on the centrality of Black women to Afro-American history, but also on their pivotal significance to present-day social and Political developments in America.

The novels of the late seventies and the eighties continue to explore these themes - that sexism must be struggled against in black communities and that sexism is integrally connected to racism. The fiction of this period - Morrison's Song of Solomon (1978) and Tar Baby (1980), Gloria Naylor's The Women of Brewster Place (1980), Toni Cade Bambara's The Salt Eaters (1980), Alice Walker's You Can't Keep a Good Woman Down (1981) and The Color Purple (1982), Joyce Carol Thomas's Marked by Fire (1982), Ntozake Shange's Sassafrass, Cypress and Indigo (1982), Audre Lorde's Zami (1982), and Paule Marshall's Praisesona for the Widow (1983)- look at ways in which the quality of Black women's lives is affected by the interrelationship of sexism and racism. They pose the question concerning to what community Black woman must belong in order to understand themselves most effectively in their totality as blacks and women.

Toni Morrison was a powerful and imaginative editor at Random House when the movement began, and her role in her generation was key. Publishing such formidable figures as Toni Cade Bambara, Gayl Jones and Angela Davis, she inspired a youner generation of writers especially Gloria Naylor. By writing several bestselling novels, Morrison demonstrated to publishing houses that a new and identifiable readership eager for a 'woman oriented' content. All of Morrison's novels, down to her last one, Home, deal with different aspects of love between individuals, not least within the family. The lack of love and the perversion of love which many of the characters in Sula, The Bluest Eye and Love suffer from are for the most part connected to the relationships between parents and children. In particular the damaging sexual behavior of males, as demonstrated in many of these relationships, is what in the end destroys the lives of young girls and women. The adults' sick sexuality is also contrasted to the pure and innocent love between children, whose capacity for love and affection is stunted, often for life, by the adults' behavior.

Alice Walker, like Toni Morrison has used her writing as a platform to champion the causes of all women. She is well noted for her prolific writings that proclaim the struggles of African American women. She is also a constant critic of established forms of feminism and later established "Womanism", a form of feminism that incorporates specific qualities common to the experiences of African American women. Alice Walker spent 
time working to fight for equality during the Civil Rights Movement. This sense of pride is quite evident in her writings. Walker's works have been duly noted for their empowerment of the female voice. Accordingly, Walker is credited for her attempt to reveal the Black women characters she felt were missing from literature in the United States. Walker asserts that these are women who have been exploited physically and emotionally; women who have been victimized, and who are able to move past their oppressions to grasp a sense of "wholeness". She has raised her voice for the ethnic woman in the postcolonial period who were silenced and relegated to an unimportant or powerless position within the society. Mary Helen Washington's "An Essay on Alice Walker" seeks to explain the reasoning behind Walker's writings. It explains her vision of the multiple experiences of Black women "as a series of movements from women totally victimized by society" (39). As victims, Washington heralds the female characters in Walker's writings as using the interior of their souls to deal with the universal problems of poverty, exploitation, and discrimination. Washington's discussion reveals a new reading of Walker's works, whereupon one studies directly the victimized African American woman.

The growing institutionalization of Afro-American literature in traditional English departments has been concomitant with the growth of Black woman's literature. Afro American studies and women's studies share a common terrain and a common discourse in the criticism of Black women's writing. As Huston Baker puts the matter "the convergence of feminist and Afro American theoretical formulations offer the most challenging nexus for scholarship in the coming years ... one aspect of that development will be the continued reshaping of the literary cannon as forgotten, neglected or suppressed texts are rediscovered."(Baker, 245)

During the last four decades remarkable transformations have taken place in Afro-American literature. Once dismissed as 'provincial' by white critics and inflicted by poor sales and little publicity, the fiction of the finest Afro-American authors in the 1980s onwards frequently appears on best-sellers' list, receives critical acclaim, rave reviews and extreme class-room use, and is regarded by many as being the most exciting - as well as controversial - writing published today. Perhaps the most significant of all, many of the pre-eminent leaders of this pioneering new fiction are Black women who, as a group, were for long the 'invisible' authors in a literary tradition almost as old as the nation itself. Their works highlight the sense of hope and aspiration or a kind of dream that is projected as a silver lining in the dark cloud of the Black women's life for a bright and happy future.

\section{References:}

[1]. Baker, Houghton A. "Autobiographical Acts and the Voices of the Southern Slave", in Charles T. Davis, and Henry Louis Gates, eds. The Slave's Narrative. New York, OUP, 1985, (242-61).

[2]. Beal, Frances, M. "Slave of a Slave No More: Black Women in Struggle", The Black Schola. Vol. 6, 6, March, 1975.

[3]. Cille, Ann Du. "The Occult of True Womanhood: Critical Demeanor and Black Feminist Studies". signs, Vol - 19, 3, Spring, 1994

[4]. Davis, Angela. Women, Race, Class. London, The Women's Press, 1981.

[5]. Evans, Mari, ed. Personal Politics. New York, Doubleday, 1985

[6]. Fine, Reuben. Narcissism: The Self and the Society. New York: Columbia University Press, 1986.

[7]. Gates Jr., Henry Louis. The Classic Slave Narratives. New York: Penguin Books, 1987.

[8]. Hooks, Bell. Feminist Theory: From Margin to Centre. Boston, South End Press, 1984.

[9]. Huston, Zora Neale. Their Eyes Were Watching God. Philadelphia: J.B. Lippincott Co., 1937.

[10]. Lerner, Garda, ed. Black Women in White America, A Documentary History. New York, vintage, 1972.

[11]. Walker, Alice. In Search of our Mothers Garden: Womanist Prose. New York, Doubleday, 1975.

[12]. Washington, Mary Helen. Black Eyed Susans: Classic Stories by and About Black Women. New York, Doubleday, 1975.

[13]. ---. "An Essay on Alice Walker". Alice Walker: Critical Perspectives Past and Present. Eds. Henry Louis Gates Jr. and K. A. Appiah. New York: Amistad, 1993.

[14]. Willis, Susan. "Black Women Writers: Taking a Critical Perspective." Making a Difference: Feminist Literary Criticism. Greene, Gayle and Coppelia Kahn, cd. London and New York : Routledge, 1985.

[15]. Willson, E Harriet. Our Nig. Boston, Geo. C. Rand \& Avery publishers, 1859. 